\title{
Effects of food prices on consumption pattern of consumers: A case study of Lafia Local Government Area Nasarawa State, Nigeria
}

\author{
Onuk, E.G. \\ Department of Agricultural Economics and Extension, Faculty of Agriculture, Nasarawa State, Keffi, Nigeria. Email: \\ galadima1954@gmail.com; Tel: 08065759101.
}

Copyright $@ 2019$ Onuk. This article remains permanently open access under the terms of the Creative Commons Attribution License 4.0, which permits unrestricted use, distribution, and reproduction in any medium, provided the original work is properly cited.

Received 7th May, 2019; Accepted 10th June, 2019

\begin{abstract}
The study examined the effects of food prices on consumption pattern of consumers in Lafia Local Government Area of Nasarawa State, Nigeria. Primary data were obtained from a sample of 100 households. The data collected were first classified according to the income level of the respondents and then descriptive statistics and analysis of variance were applied. The result of the study indicated that about $36 \%$ of the respondents fell within the age bracket of 41 to 50 years while $76 \%$ of the respondents were male and $94 \%$ of the respondents were married. The result further showed that $42 \%$ of the respondents had a family size of between 6 to 10 persons. Also $49 \%$ of the respondents had at least tertiary education and $40 \%$ were civil servants and $59 \%$ of the respondents were high income earners. The study indicated the consumption pattern of the respondents and revealed that the three categories of income groups consumed almost the same quantity of basic food items. Meanwhile the result also showed that higher expenditure was observed amongst the lower income groups for rice, cowpea, palm oil and yam with frequencies of 15.0, 15.1, 8.3 and 8.3\% respectively. There was significant difference between the income groups as determined by the one-way analysis of variance $(F=3.4)$ with cowpea highly significant at $5 \%$ level. The study also revealed the major cause of variations in food prices which included high cost of transportation, farmers/herdsmen clashes, and removal of fertilizer subsidy among others. Based on the findings, the study recommends that government should intervene through food policy to mitigate the effects of food price volatility and government should try and end the clashes between farmers and herdsmen in important producing states.
\end{abstract}

Keywords: Consumers, consumption pattern, food prices, headed households, income groups.

\section{INTRODUCTION}

The consumption pattern is one of the most important drivers of the development pattern of industrialized nation. The main factor explaining food consumption pattern is the level of disposable income. However, consumption pattern changes not only measures in the amount of calories consumed with the rising income, but also the share of animal products in overall diets. There are other additional explanatory factors that determine consumption pattern rather than income like culture, religion or possibly lifestyle choices. Moreover, the consumption structure differs widely even at the same high-income level (Anyanwu, 2011).
The pattern of Nigeria food consumption has been undergoing dramatic changes over the years due to fluctuations in economy growth and living standard driven by oil revenues. The consumption of meats, dairy products, rice, fish, fresh fruits and processed vegetables has been increasing. Many factors have influenced Nigeria food consumption pattern like higher growth rate of population and a more westernized lifestyle. Some years back, Nigeria market depended on other nations markets to cover her domestic demand for food products e.g. rice imported from Thailand and the people's Republic of China which represented about $16 \%$ of total merchandize 
imports in 2010 (Anyanwu, 2011). However, Nigeria is expected to cover its food needs from domestic production with present government policies on Agriculture.

As a result of various agricultural policies of the present Nigeria government, the food markets have become more vulnerable to changes and fluctuation in prices. Recently, soaring food prices have become a major concern amongst many policy makers. For example, the group of 20 developed and leading emerging economy (G20) has put the food price spike and food security at the top of their agenda (Alem and Soederbon, 2016).

In due time after the sharp decline from their peak in the second half of 2017, the Nigeria food prices soared again. Prices for cereals, roots and tubers, cooking oils and sugar increased most, while the increases of meat and fish prices were moderate. National Supply and demand in balance in agricultural commodity markets appear to have been a main driving factor for this recent increase. Fulani herdsmen and farmers clashes in important producing states, growing nations population and flooding which have affected the production and supply of foods are the main drivers of food prices across Nigeria (Umaru and Zubairu, 2012). Other factors driving food prices (both supply and demand sides) are higher energy prices, higher petroleum prices and higher transportation prices.

Nigeria consumers are not immune from the effect of high national food prices. High food prices might inevitably erode the Nigeria household's purchasing power, especially low-income households reducing equity and efficiency standards (World Bank, 2014). Thus, it is important to investigate how consumers react and adjust to high food prices and evaluate the specification of consumers to the future food market. This paper investigated how households in Lafia local government area of Nasarawa State coped with higher food prices based on the survey of selected group of households. As far as Nigeria is concern, in respect of high food prices, the country has experienced worst food crisis and price hike in the recent time.

Kyle and Swinnen (1994) concluded that high food prices have caused day to day changes in consumption pattern of consumers especially of commodities such as rice, yam, wheat etc. These changes in consumer consumption patterns affect the savings of consumers and uncertainty prices, both of food and non-food items generate enthusiasm among people towards earning more and more. Therefore, people prefer to work more and earn more money over recreation thus underestimating their health. Over working for more money and lack of recreation makes especially the middle-class people vulnerable and may fall into the lower class. Compton et al. (2010) found that higher food prices bring negative impact on Nigeria economy and suggested that large scale commercial agricultural activities should be encourage to enhance the economic growth. This will create numerous job opportunities which increases the per-capita earning and living standard of consumers.
This study is expected to be useful to policy makers especially in formulating policies that will reduce high food prices and ensure lower cost of living. Findings and recommendations from this study are also expected to be of great benefits to agricultural institutions in Nigeria, particularly, the recommendations, if implemented will go a long way in guaranteeing sustainable and sound economy. The study will also be of great benefit to researchers who have interest in researching more into food prices and cost of living. It will also act as guide to student researchers who will be interested in carrying out further research on the effects of food prices on consumption pattern of consumers.

\section{Objective of the study}

The objectives of this study are to determine:

1. the socio-economic characteristics of consumers in the study area.

2. the changes in consumption of basic food products after price change.

3. the expenditures increase on consumption of basic food products.

4. the causes of variation in food prices

\section{METHODOLOGY}

\section{The study area}

The study was conducted in Lafia Local Government Area, Nasarawa state which is located in the southern zone of Nasarawa state, Nigeria. It lies along latitude $8^{0} 29^{\circ}$ north, longitude $8^{0} 31^{\circ}$ east and about $181.5 \mathrm{~m}$ altitude above the sea level (NADP 2009). The study area shares boundaries with Nasarawa Eggon Local Government Area to the south, Doma Local Government Area to the west and Qua'an Pan Local Government Area of Plateau State to the east. The local government has a population of about three hundred and thirty thousand, seven hundred and twelve $(330,712)$ inhabitants (NPC, 2006). Lafia local government has generally warm climate characteristic thus being the result of its relatively low attitude. The minimum temperature ranges from 11 to $12^{\circ} \mathrm{C}$ in December/January and to maximum of 33 to $42^{\circ} \mathrm{C}$ between March/April. The mean annual rainfall in 527.8 $\mathrm{mm}$ which begins in March/April and end in October/November and its soil varies from sand to clay based on its climate weather condition. The following crops such as yam, cassava, maize, sorghum, rice amongst others are grown in the area. The people of Lafia local government are predominantly farmers and they also engaged in other economic activities like fishing, trading, craft, tailoring, weaving, carvings, amongst others. 


\section{Sampling technique}

A cross sectional study was conducted in Lafia to study the effects of higher food prices on consumption pattern of households. Five districts namely; Akunza, Lafia East, Lafia North, Agyaragun Tofa and Lafia Central were selected out of the thirteen districts of Lafia local government area. From these, a purposive simple random sampling was used to select twenty households, bring to a total of one hundred consumers for the study. This procedure is to ensure that every member of the target population will have an equal chance of being selected or not selected for the research study.

\section{Data collection and analysis}

The primary data was collected using a well-structured questionnaire in which the respondents were randomly selected. Secondary sources such as text books, journals, proceedings and thesis were also consulted. The analytical tools that were used for this research include descriptive statistics, using frequency tables and cross tabulation to achieve objectives 1,2 and 4 respectively. ANOVA was used to achieve objective 3 . The data was first grouped and classified according to the income level of the respondents and then the analysis was performed. This classification allows for more vigorous analysis to indicate which groups are most affected by high food prices. The respondents were classified based on income groups taking into accounts the living standard of the population according to the following criteria; Those with income less than $\mathrm{N} 2,500$ per month were classified in the middle income group; and those with income range of $\mathrm{N} 2,500$ to $\mathrm{N10,000}$ per month were classified in the middle income group, and those with income higher than $\mathbf{N 1 0 , 0 0 0}$ per month were classified in the higher income group.

\section{RESULTS AND DISCUSSION}

\section{Socio-economic characteristics of the respondents}

The socio-economic factors that affect consumption pattern and consumer behavior of individuals and their responses to the changes in commodity prices such as gender, age, marital status, occupation, household size, educational level, among others are considered in this part of analysis. The result in Table 1 shows the socioeconomic profile of the respondents in the study area. About $36 \%$ of the total respondents were within the age bracket of 41 to 50 years, $19 \%$ were within 20 to 31 years, $24 \%$ were within 31 to 40 years and $21 \%$ were within 51 to 60 years. This indicated that most of the household's heads were still in their active ages and in sound mental ability to keep the records of basic food expenditure of their household. This is in line with the findings of Alem and
Table 1. Socio-economic characteristics of the respondents.

\begin{tabular}{|c|c|c|}
\hline Variable & Frequency & Percentage (\%) \\
\hline \multicolumn{3}{|l|}{ Age (Years) } \\
\hline 20 to 30 & 19 & 19 \\
\hline 31 to 40 & 24 & 24 \\
\hline 41 to 50 & 36 & 36 \\
\hline 51 to 60 & 21 & 21 \\
\hline \multicolumn{3}{|l|}{ Gender } \\
\hline Male & 76 & 76 \\
\hline Female & 24 & 24 \\
\hline \multicolumn{3}{|l|}{ Marital Status } \\
\hline Married & 94 & 94 \\
\hline Divorced & 2 & 2 \\
\hline Widows & 4 & 4 \\
\hline \multicolumn{3}{|l|}{ Educational Level } \\
\hline Primary & 15 & 15 \\
\hline Secondary & 18 & 18 \\
\hline Tertiary & 49 & 49 \\
\hline Non formal & 18 & 18 \\
\hline \multicolumn{3}{|l|}{ Occupation } \\
\hline Farming & 20 & 20 \\
\hline Trading & 29 & 29 \\
\hline Civil servant & 40 & 40 \\
\hline Mechanic & 1 & 1 \\
\hline Tailoring & 3 & 3 \\
\hline Driving & 7 & 7 \\
\hline \multicolumn{3}{|l|}{ Household size } \\
\hline 1 to 5 & 27 & 27 \\
\hline 6 to 10 & 42 & 42 \\
\hline 11 to 15 & 14 & 14 \\
\hline 16 to 20 & 14 & 14 \\
\hline$>20$ & 3 & 3 \\
\hline \multicolumn{3}{|l|}{ Income groups } \\
\hline Lower income & 16 & 16 \\
\hline Medium income & 27 & 27 \\
\hline Higher income & 57 & 57 \\
\hline
\end{tabular}

Source: Field Survey, 2018.

Soederbon, (2016) in their work titled 'household level consumption in rural Ethiopia' reported that the average age (43 years) of the household heads were in their active age and have good memory of their basic food expenditure.

The result further revealed that majority $(76 \%)$ of the respondents were male while the remaining $(24 \%)$ were female. This implies that most of the household heads in 
Table 2. Changes in consumption pattern of the respondents.

\begin{tabular}{lccc}
\hline Commodities & Low income & Medium income & Higher income \\
\hline Rice $(\mathrm{kg})$ & 22.0 & 23.3 & 24.1 \\
Millet $(\mathrm{kg})$ & 3.7 & 2.0 & 1.0 \\
Sorghum $(\mathrm{kg})$ & 4.1 & 2.0 & 1.1 \\
Cowpea $(\mathrm{kg})$ & 13.0 & 11.0 & 11.4 \\
Yam (tubers) & 10 & 12 & 20 \\
Cassava (kg) & 6.0 & 4.0 & 2.6 \\
Beef $(\mathrm{kg})$ & 3.0 & 7.0 & 8.5 \\
Milk (kg) & 2.0 & 4.0 & 5.2 \\
Sugar (kg) & 6.0 & 6.0 & 6.5 \\
Palm oil (liter) & 10 & 8.0 & 8.0 \\
Groundnut oil (liters) & 3.0 & 6.2 & 6.8 \\
Fish (kg) & 3.0 & 4.8 & 5.9 \\
\hline
\end{tabular}

Source: Field survey, 2018.

the study area were men. The findings also indicated that $94 \%$ of the total respondents were married, while 2 and $4 \%$ were divorced and widows respectively. Matrimonial relationship readily implies that the household heads could be expected to make rational decisions since their household's members could rely on them to provide for their basic food commodities (Adesina, 2015). The result in Table 1 further revealed that $40 \%$ of the total respondents were civil servants, while 20, 29, 1, 3 and $7 \%$ were farmers, traders, mechanic, tailors, and drivers respectively. The implication of this result is that Lafia Local Government which is the seat of Government of Nasarawa State had high percentage of civil servants.

Education is very important as it determines or influences the decision of the household's heads either to buy a particular food commodity or not to buy due to change in market price. Table 1 show that $49 \%$ of the total respondents had at least Tertiary education, while 15\% had primary education, $18 \%$ had secondary, and $18 \%$ nonformal education in that order. The implication of this result is that majority of the respondents had one form of formal education or the other. Hence, their literacy level may enable them to remember the records of their basic food consumption. Haruna (2011) also confirmed this in his work titled "comparative analysis of gender involvement in Agricultural production". He reported that the level of education determines the ability of household heads to remember the quantities of food items consumed in their households.

The household size revealed that $42 \%$ of the total respondents had 6 to 10 persons in the family while 27,14 , 14 and $3 \%$ had 1 to 5,11 to 15,16 to 20 and $>20$ persons in the family respectively. The implication of this finding is that the household heads spent more money in buying basic food since the family size in the study area is large. Ugu (2009) in his research titled "supply and demand in changing market prices of food" carried out in Karu Local Government Area of Nasarawa state observed a family size of 6 to 10 persons. This could also be as a result of practicing of polygamy by many of the respondents. The result further showed the classification and grouping of data according to the income of the respondents. The higher income group dominated the selected respondents by $57 \%$, while medium income group account for $27 \%$ and the rest $16 \%$ of the respondents belong to the lower income group.

\section{Changes in consumption pattern of the respondents}

The changes in consumption pattern of the selected respondents for the three categories of income groups is almost identical as indicated in Table 2. The respondents almost consumed the same quantity of basic food items which is between 22 and $24.1 \mathrm{~kg}$ for rice and 10, 10.7 and $10.9 \mathrm{~kg}$ for yam. While there was a great difference in the quantity of milk consumed, lower income group consumed $2.0 \mathrm{~kg}$ and the higher income groups consumed $5.2 \mathrm{~kg}$. This result reflects the difference in the standard of living of the respondents in the consumption of fat/proteins and there is no much difference between lower income group and high income group in basic food needs. This conforms to the research work of ljeoma (2012), titled "causes and consequences of rising food prices in Akwa Ibom", a case study of Eket-Ekpene where her findings revealed that the respondents almost consume the same quantity of basic food commodities in the study area.

\section{Expenditure increases on the consumption of basic food commodities}

Table 3 showed that the respondents' expenditure on food products increased. Using ANOVA, the result revealed that high food expenditure makes lower income group more fragile and sensitive to future increase in food prices 
Table 3. Expenditure increases on the consumption of basic food commodities, in percent.

\begin{tabular}{lcccc}
\hline Commodities & Lower Income & Medium Income & Higher Income & F-Value \\
\hline Rice $(\mathrm{kg})$ & 15.0 & 11.1 & 8.4 & 2.4 \\
Millet & 8.5 & 7.5 & 8.2 & 0.3 \\
Sorghum & 8.3 & 7.3 & 8.0 & 0.2 \\
Cowpea & 15.1 & 10.3 & 8.4 & $3.4^{*}$ \\
Yam & 8.3 & 7.2 & 7.3 & 0.2 \\
Cassava & 5.6 & 9.7 & 8.8 & 2.6 \\
Beef & 11.8 & 9.8 & 7.7 & 0.5 \\
Milk & 7.0 & 8.5 & 6.9 & 0.6 \\
Sugar & 8.1 & 9.8 & 6.8 & 2.3 \\
Palm Oil & 8.3 & 7.1 & 7.2 & 0.1 \\
Groundnut Oil & 7.2 & 8.3 & 7.3 & 0.2 \\
Fish & 7.2 & 9.6 & 7.5 & 1.2 \\
\hline
\end{tabular}

*Significant at $5 \%$.

Source: Field survey, 2018.

Table 4. Causes of variation in food prices.

\begin{tabular}{lccc}
\hline Causes & Frequency & Percentage & Rank \\
\hline Increase of National food price & 34 & 8.0 & 6 th \\
Absence of food subsidy & 27 & 6.2 & 8 th \\
Lower agricultural input & 29 & 6.7 & 7 th \\
Removal of fertilizer subsidy & 53 & 12.3 & $3 \mathrm{rd}$ \\
High cost of Transportation & 75 & 17.4 & $1 \mathrm{st}$ \\
Bad road network & 68 & 15.9 & $2 \mathrm{nd}$ \\
Farmers/Herdsmen clashes & 68 & 15.9 & $2 \mathrm{nd}$ \\
Wholesaler monopoly & 39 & 9.0 & 4 th \\
Poor government policy & 36 & 8.3 & 5 th \\
Total & 429 & 100 & \\
\hline
\end{tabular}

Multiple responses existed.

Source: Field survey, 2018.

which might curtail their ability to provide their basic needs. FAO (2008) reported that food price volatility affects lower income earners the most which makes them to be aware of future food price increase. Furthermore, the result from Table 3 also revealed that higher expenditure increase was observed amongst the lower income groups for rice, cowpea, palm oil and yam which are 15.0, 15.1, 8.3, and $8.3 \%$ respectively. There is no significant difference between the three income groups in expenditure increase for millet, sorghum, and fish. There was a statistical significant difference between the groups as determined by one-way analysis of variance $(\mathrm{F}=3.4)$ with cowpea highly significant at $5 \%$ level (i.e. $p<0.05$ ). The highly significant rate of cowpea was earlier reported from the study area by Ovey (2011) in his work titled "economic analysis of cowpea production" in Lafia Local Government Area of Nasarawa state. He reported that there are significant variations in the prices of cowpea across the selected markets investigated over the years.

\section{Causes of variation in food prices}

Table 4 indicated the responses of the respondents on reasons for variation in food prices in the study area. The majority (17.4\%) of the respondents agreed that high cost of transportation is the cause of variation in food prices. This finding agrees with Adesina (2015) in his report "overview of the nature and impact of the 2008 food crisis in Nigeria". He stated that high cost of transportation in Nigeria in 2008 occasioned by the increase in the international price of petrol was transmitted to the domestic economy leading to an escalation of the transport cost on many food crops. The result of the findings also indicated that bad road network, famers/herdsmen clashes, were severe in causing variation in food prices. Other causes in variation in food prices include removal of fertilizer subsidy, wholesaler monopoly, poor Government policy, increase of national food price, absence of food subsidy and lower agricultural 
input in the study area.

\section{Conclusion}

From the results obtained, the consumption pattern of the selected respondents for the three categories of income group revealed that most of the respondents consumed almost the same quantity of basic food items. The result further indicated that there was statistically significant difference between the income groups as determined by one-way analysis of variance ( $F=3.4)$ with cowpea highly significant at $5 \%$ level. The result also identified the major causes of variation in food prices in the study area which were high cost of transportation, bad road network, farmers/herdsmen clashes, and removal of fertilizer subsidy, among others.

The study concluded by recommending a number of measures that will help to reduce high food prices on consumers as follows, Government should intervene through food policy to mitigate the effects of food price volatility, Government should increase investment in infrastructure especially on rural roads to reduce problems of transportation, Government should try and end the clashes between farmers and herdsmen in important producing states and Government should also try and improve the market information system as this will reduce market speculations, price hikes, and uncertainty. Finally, large scale commercial agricultural activities should be encouraged to enhance economic growth. This will create numerous job opportunities which increases the per capita earning and living standard of consumers.

\section{CONFLICT OF INTEREST}

The author declares no conflict of interest.

\section{REFERENCES}

Adesina, A. (2015). Agricultural Transformation Agenda: 2014 Report Scorecard. Federal Ministry of Agriculture and Rural Development, Abuja. Nigeria. Agriculture and retail prices. Note for the file, Brussels, CM D.

Alem, Y., \& Soederbom, M., (2016). Household-level consumption in urban Ethiopia: the effects of a large food price shock. World Development, 40(1), 146-162.
Anyanwu, C. (2011). President Babangida's Structural Adjustment Programme and Inflation in Nigeria. Journal of Social Development in Africa, 7(1) 5-24.

Compton, J., Wiggins, S., \& Keats, S. (2010). Impact of the global food crisis on the poor: what is the evidence? Overseas Development Institute and UK Department for International Development, 2010.

FAO (2008). The 2007-08 Rice Price Crisis: How policies drove up prices... and how they can help stabilize the market, Economic and Social Perspectives, Policy Brief No. 13.

Haruna, A. F. (2011). Comparative analysis of gender involvement in Agricultural production in Nigeria. Journal of Development and Agricultural Economics, 4(4), 240-244.

ljeoma, E. C (2012). Causes and consequences of rising food prices in Akwa-lbom State. A Case Study of Eket-Ekpene: An unpublished thesis of the Department of Economics University of Uyo.

Kyle, S. C., \& Swinnen, J. (1994). The theory of contested markets and the degree of tradedness of agricultural commodities: An empirical test in Zaire. Journal of African Economies, 3(1), 93-113.

Nasarawa Agricultural Development Programme (NADP) (2009). Strategies for poverty reduction in Nasarawa State. A handbook published by Planning and Evaluation Department, NADP, Nasarawa State. 43p.

NPC (2006). National Population Commission (2006) Nigeria Population census.

Ovey, A. (2011): Economic analysis of cowpea production in Lafia Local Government Area of Nasarawa state. An unpublished Undergraduate Project of the Department of Agric Economics and Extension. Faculty of Agriculture, Nasarawa State University, Keffi.

Ugu A. E (2009). Supply and demand in changing market prices of food. Journal of Resources Economics, 11(2), 115-118.

Umaru, A., \& Zubairu, A. A. (2012). Effect of inflation on the growth and development of the Nigerian economy (An empirical analysis). International Journal of Business and Social Science, 3(10), 183-191.

World Bank (2014). High Food Prices, Latin American and the Caribbean Responses to a New Normal. Washington, DC. (C) World Bank. Available at https://openknowledge. worldbank.org/handle/ 10986/18639. 